\title{
24. DINOFLAGELLATES FROM LEG 19, SITES 183 AND 192 DEEP SEA DRILLING PROJECT
}

\author{
W. R. Evitt, Department of Geology, Stanford University
}

\section{SUMMARY}

Twelve samples from Sites 183 and 192 were processed by standard palynological methods and were examined for dinoflagellates and other palynomorphs. The only identifiable dinoflagellates encountered were from Site 183, Core $35(390 \mathrm{~m})$ and represented a single species, Areosphaeridium diktyoplokus (Klumpp). Other samples yielded pollen and spores. Results are in Table 1. Although the single dinoflagellate identified does not require that the upper Eocene at Site 183 was deposited at a high latitude, the same species does occur in sediment of similar age on Adak Island. The spores and pollen from other Eocene horizons at Site 183 suggest that the locus of deposition was both nontropical and relatively near shore, in contrast to tropical and open ocean. The three samples processed from Site 192 failed to yield any recognizable fossil remains.

\section{BEARING OF PALYNOMORPHS ON LOCUS OF DEPOSITION OF UPPER EOCENE SEDIMENTS FROM SITE 183}

Areosphaeridium diktyoplokus (Klumpp) is a distinctive species of dinoflagellate with a broad geographic distribution, especially well documented in the upper Eocene. To the occurrences summarized by Eaton (1971, p. 360), which include Lower Tertiary (mostly upper Eocene) records from Europe, South America, and Antarctica, can be added an occurrence in upper Eocene sediments on Adak Island in the Aleutians (Scholl, Greene, and Marlow, 1970). Although this common feature of Adak and Site 183 sediments would be consistent with proximity of the two areas in the late Eocene, the occurrence of this lone species of dinoflagellate in the upper Eocene at Site 183, in view of the known broad geographic distribution of the species, does not require this interpretation. On the other hand, the likelihood that deposition at Site 183 in the middle and late Eocene took place not too far from sources of land-derived materials is favored by the conspicuous, if not large, number of spores, gymnosperm pollen, and angiosperm pollen that was recovered from samples below that providing $A$. diktyoplokus. The presence of pollen of Tsuga and Alnus, among others, points to nontropical sources for the pollen.

\section{Systematic Paleontology \\ Class DINOPHYCEAE}

Genus AREOSPHAERIDIUM Eaton 1971

Areosphaeridium diktyoplokus (Klumpp 1953)

(Plate 1, Figures 1-2)

Hystrichosphaeridium diktyoplokus Klumpp 1953, Palaeontographica $103(5-6)$, p. 392, pl. 18, figs. 3.7.

TABLE 1

Dinoflagellates, Spares, and Pollen - Leg 19

\begin{tabular}{|c|c|c|c|c|c|c|}
\hline Site & Core & $\begin{array}{l}\text { Depth } \\
\text { (m) }\end{array}$ & $\begin{array}{c}\text { Stanford } \\
\text { Sample No. }\end{array}$ & Indicated Age & Dinoflagellates & Spores and Pollen \\
\hline \multirow[t]{9}{*}{183} & 23 & 230 & 4273 & $\begin{array}{l}\text { Oligocene or lower } \\
\text { Miocene }^{\mathrm{a}}\end{array}$ & None. & Gymnosperm pollen. \\
\hline & 26 & 255 & 4277 & lower(?) Oligocene ${ }^{a}$ & A few fragments. & $\begin{array}{l}\text { Abundant angiosperm and } \\
\text { gymnosperm pollen. }\end{array}$ \\
\hline & 30 & 285 & 4282 & lower(?) Oligocene $\mathrm{a}^{\mathrm{a}}$ & None. & None. \\
\hline & 33 & 342 & 4285 & lower(?) Oligocene $e^{a}$ & A few fragments. & $\begin{array}{l}\text { Abundant angiosperm and } \\
\text { gymnosperm pollen, rare } \\
\text { spores. }\end{array}$ \\
\hline & 34 & 360 & 4286 & Eocene-Oligocene $^{\mathrm{a}}$ & None. & A few grains only. \\
\hline & 35 & 390 & 4287 & Upper or middle Eocene & $\begin{array}{l}\text { Areosphaeridium } \\
\text { diktyoplokus and } \\
\text { other fragments. }\end{array}$ & None. \\
\hline & 36 & 415 & 4288 & Upper or middle Eocene ${ }^{a}$ & None. & $\begin{array}{l}\text { Rare gymnosperm and } \\
\text { angiosperm pollen. }\end{array}$ \\
\hline & 37 & 445 & 4289 & middle or middle Eocene ${ }^{a}$ & None. & $\begin{array}{l}\text { Rare gymnosperm and } \\
\text { angiosperm pollen. }\end{array}$ \\
\hline & 38 & 475 & 4290 & middle or lower Eocene ${ }^{\mathrm{a}}$ & None. & Rare gymnosperms only. \\
\hline \multirow[t]{3}{*}{192} & $3 a$ & 975 & 4297 & lower upper Eocene ${ }^{a}$ & None. & None. \\
\hline & $4 a$ & 1020 & 4298 & Maestr.-Eocene ${ }^{a}$ & None. & None. \\
\hline & $5 \mathrm{a}$ & 1045 & 4299 & M. Maestrichtian ${ }^{\mathrm{a}}$ & None. & None. \\
\hline
\end{tabular}

${ }^{\mathrm{a}}$ Based on nannofossil assignments. 

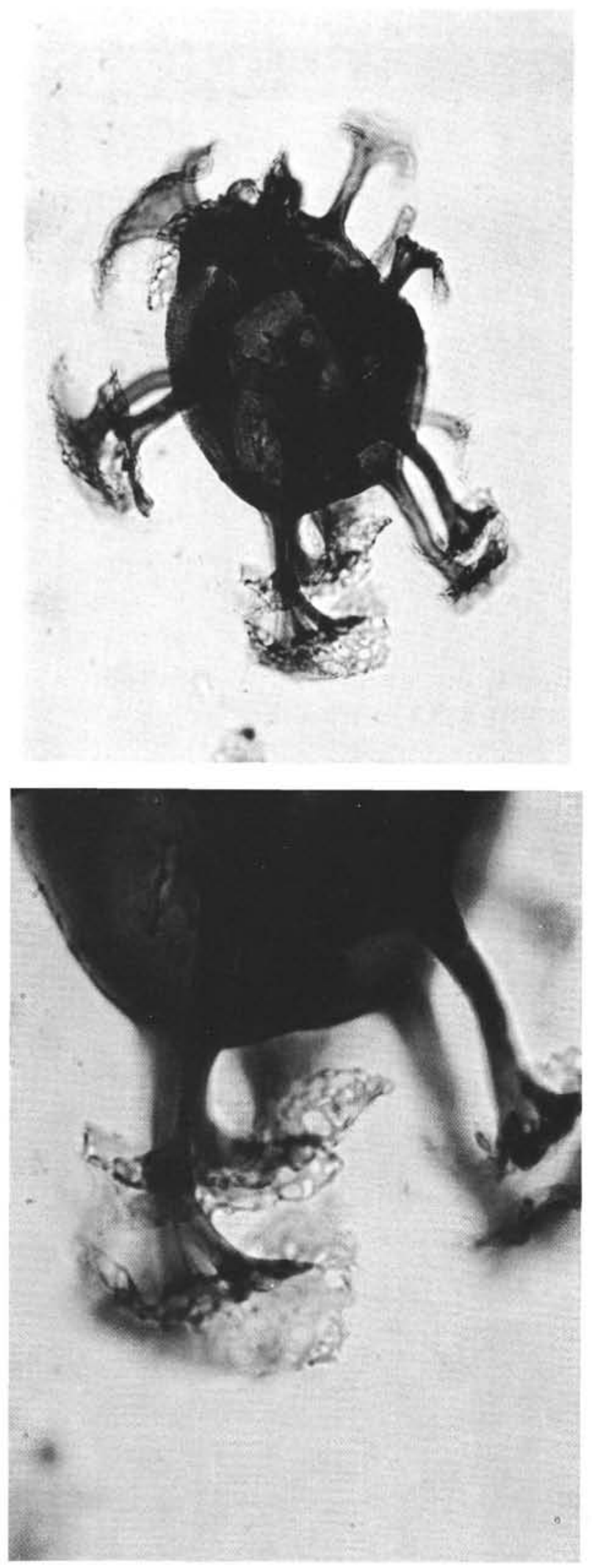

Figures 1 and 2. Areosphaeridium diktyoplokus (Klumpp). Core 183-25.

1. Cyst lacking only the operculum, $\times 525$.

2. Detail showing characteristic perforate structure of process tips, $\times 1150$.
Cordosphaeridium diktyoplokus (Klumpp) Eisenack, 1963, Neues Jahrb. Geol. Paläont., Abh., 118 (3), p. 262, pl. 29, fig. 1.

Areosphaeridium diktyoplokus (Klumpp) Eaton, 1971, II Planktonic Conference, Rome 1970, Proc., p. 358, pl. 1, figs. 3-8; pl. 2 , figs. $1-6$.

(see last reference for complete synonymy)

Remarks: The approximately spherical main body, the number and distribution of the long and fibrous-appearing processes surmounted by elaborately perforate expansions, and the apical archeopyle are completely typical for the species as discussed most recently and thoroughly by Eaton.

\section{REFERENCES}

Eaton, G. L., 1971. A morphogenetic series of dinoflagellate cysts from the Bracklesham Beds of the Isle of Wight, Hampshire, England. In Proceedings of the II Planktonic Conference, Roma 1970, 355.

Eisenack, Alfred, 1963. Cordosphaeridium n. g., ex Hystrichosphaeridium, Hystrichosphaeridea. Neues Jahrb. Geol. Palaont. 118(3), 260.

Klumpp, Barbara, 1953. Beit-ag zur Kenntnis der Mikrofossilien des mittleren und oberen Eozan. Palaeontographica, A, 103(5-6), 377.

Scholl, D.W., Greene, H.G., and Marlow, M.W., 1970. Eocene age of Adak "Paleozoic(?)" rocks, Aleutian Islands, Alaska. Bull. Geol. Soc. Am. 81, 3582. 